Research Article

\title{
Evolution of flatworm central nervous systems: Insights from polyclads
}

Sigmer Y. Quiroga ${ }^{1, \S}$, E. Carolina Bonilla ${ }^{3, \S}$, D. Marcela Bolaños ${ }^{2,3, \S}$, Fernando Carbayo ${ }^{4,5}$, Marian K. Litvaitis ${ }^{2}$ and Federico D. Brown ${ }^{3,5,6,7}$

${ }^{1}$ Programa de Biología, Facultad de Ciencias Básicas, Universidad del Magdalena, Santa Marta, Colombia. ${ }^{2}$ Department of Natural Resources and the Environment, University of New Hampshire, Durham, NH, USA.

${ }^{3}$ Laboratorio de Biología del Desarrollo, Departamento de Ciencias Biológicas, Universidad de los Andes, Bogotá, Colombia.

${ }^{4}$ Laboratório de Ecologia e Evolução, Escola de Artes, Ciências e Humanidades, Universidade de São Paulo, São Paulo, SP, Brazil.

${ }^{5}$ Programa de Pós-Graduação em Zoologia, Departamento de Zoologia, Instituto de Biociencias, Universidade de São Paulo, São Paulo, SP, Brazil.

${ }^{6}$ Departamento de Zoologia, Instituto de Biociências, Universidade de São Paulo, São Paulo, Brazil.

${ }^{7}$ Centro de Biologia Marinha, Universidade de São Paulo, São Sebastião, Brazil.

\begin{abstract}
The nervous systems of flatworms have diversified extensively as a consequence of the broad range of adaptations in the group. Here we examined the central nervous system (CNS) of 12 species of polyclad flatworms belonging to 11 different families by morphological and histological studies. These comparisons revealed that the overall organization and architecture of polyclad central nervous systems can be classified into three categories (I, II, and III) based on the presence of globuli cell masses -ganglion cells of granular appearance-, the cross-sectional shape of the main nerve cords, and the tissue type surrounding the nerve cords. In addition, four different cell types were identified in polyclad brains based on location and size. We also characterize the serotonergic and FMRFamidergic nervous systems in the cotylean Boninia divae by immunocytochemistry. Although both neurotransmitters were broadly expressed, expression of serotonin was particularly strong in the sucker, whereas FMRFamide was particularly strong in the pharynx. Finally, we test some of the major hypothesized trends during the evolution of the CNS in the phylum by a character state reconstruction based on current understanding of the nervous system across different species of Platyhelminthes and on up-to-date molecular phylogenies.
\end{abstract}

Keywords: brain, FMRFamide, globuli cell masses, orthogon, serotonin.

Received: January 13, 2015; Accepted: April 19, 2015.

\section{Introduction}

Current phylogenetic views of Platyhelminthes divide the phylum into Catenulida and Rhabditophora (Laumer and Giribet, 2014; Laumer et al,. 2015; Egger et al., 2015). Within the diverse Rhabditophora, strong morphological and molecular evidence suggests Macrostomorpha as the basal clade; whereas Polycladida, often considered a basal clade (for a review see Baguñà and Riutort, 2004; Karling, 1967, 1974; Carranza et al,. 1997, Litvaitis and Rhode, 1999; Laumer and Giribet, 2014), currently groups together with the Prorhynchida in a more derived position based on recent phylogenomic and transcriptomic analyses

Send correspondence to Federico D. Brown. Departamento de Zoologia, Instituto de Biociências, Universidade de São Paulo, Rua do Matão, Travessa 14, No. 101, Cidade Universitária, 05508-090 São Paulo, SP, Brazil. E-mail: fdbrown@usp.br.

${ }^{\S}$ These authors contributed equally to the present work.
(Laumer et al., 2015; Egger et al., 2015). The main characteristic of the Polycladida is their highly branched intestine (Hyman, 1951), from which they derive their name. Polyclads have few external traits; however, the presence or absence of clusters of eyespots and either true tentacles or pseudotentacles, which form by folds of the anterior body margin, can be used as systematic characters (Newman and Cannon, 1994). The initial division of the order is based on the presence or absence of a ventral sucker. This character divides the polyclads into the two suborders Acotylea (without sucker) and Cotylea (with sucker) (Lang, 1884).

Among invertebrates, nervous systems exhibit a wide variety of organization, which can range from an unorganized diffuse nerve net (cnidarians) to complex systems with highly specialized sensory receptors (arthropods, some mollusks) (Ruppert and Barnes, 1994). The bilaterally flattened body of flatworms preserves a common orga- 
nization of the central nervous system (CNS). The CNS of flatworms consists of: (i) the orthogon, composed of main longitudinal nerve cords and transverse commissures that form a ladder-like network. The main cords have direct connections to the brain, are generally multifibrillar, are more strongly developed on the ventral side, and express serotonin or cholinergic neuropeptides (Reuter and Gustafsson, 1995). The number, position, and arrangement of cords vary drastically from one taxonomic group to the next; (ii) an anterior brain consisting of two lobes connected by one or several commissures. The lobes may be either loosely aggregated or encapsulated by a sheath of extracellular matrix (Reuter and Gustafsson, 1995); and (iii) the plexus, composed of a network of sub- and infraepidermal, or submuscular nerves that expand throughout the body of the worm. In addition, in free-living flatworms the presence of pharyngeal and stomatogastric plexi, consisting of either one or two nerve rings, innervated by suband infra-epithelial nerve nets (Reuter and Gustafsson, 1995; Halton and Gustafsson, 1996), are considered plesiomorphic characters (Ehlers, 1985).

Reisinger (1925) defined a standard orthogonal pattern for many free-living forms. This pattern consists of several pairs of ventral, lateral, and dorsal longitudinal nerve cords that are connected at right angles along their lengths by transverse commissures, forming a ladder-like arrangement. Although the orthogon organization and occurrence does not show clear evolutionary trends (Reuter and Gustafsson, 1995), a common origin of the CNS in flatworms has been suggested with convergent evolution of similar orthogonal organizations in different taxa (Kotikova, 1991). The orthogon varies in position and number of cords, different points of contact with the brain, and thickness of cords. Reuter et al. (1998) determined that the main cords derive from strong roots in the brain, are composed of numerous neurons within wide fiber bundles, and generally show immunoreactivity for serotonin and catecholamines. It has been hypothesized that more derived clades often have fewer but thicker nerve cords than more basal taxa (Reisinger, 1972; Reuter and Gustafsson, 1995), and that longitudinal cords may have evolved from the fusion of plexal fibers of ancestral taxa (Joffe and Reuter, 1993).

The architecture of the polyclad nervous system reflects components of the anatomically diffuse cnidarian system and of a centralized and more condensed nervous system found in the higher invertebrates (Koopowitz, 1974). They have been characterized as being among the most advanced in flatworms with complexities comparable to those of segmented marine worms (Bullock and Horridge, 1965). At the same time, the peripheral nervous system, and especially a nerve plexus located at the base of the epithelium (infraepithelial plexus) exhibits an organization similar to that of the nerve net found in hydra (Chien and Koopowitz, 1977). Additionally, the polyclad nervous system lacks ganglia other than those found in the brain.
As part of a comprehensive and comparative study of ca. 20 species of polyclads from the Gulf of Naples, Lang (1884) unified early descriptions of the main morphological features in polyclad nervous systems. Detailed histological descriptions of the CNS are available for the cotylean, Thysanozoon brocchii Risso, 1818 (Lang, 1884) and more recently for the acotylean, Notoplana acticola Boone, 1929 (Koopowitz, 1973, 1986; Chien and Koopowitz, 1972, 1977; Koopowitz and Chien, 1974, 1975). The CNS consists of an anterior, bilobed brain that functions in coordinating locomotion and peripheral reflex activity (Koopowitz, 1973). In both species, this brain is enclosed by a distinct capsule and is composed of an outer rind of cells, formed by a variety of neuronal types (e.g., multipolar, decussating, coupled), and an inner core of thin fibers and a complete lack of nuclei or cell bodies (Lang, 1884; Koopowitz, 1986). In T. brocchii, the largest, multipolar ganglion cells are mostly confined to the dorsal, ventral, and posterior parts of the brain. Thin fibers in the core of the brain form a complex anastomosing network, which gives rise to the nerve cords exiting the brain (Lang, 1884). At the front of each brain lobe and located outside the capsule are two groups of sensory ganglion cells (globuli cell masses, or Körnerhaufen in the original German terminology) that are of granular appearance. Furthermore, Stylochoplana maculata Quatrefage, 1845, N. acticola, Planocera Lang, 1879, and Gnesioceros Diesing, 1862 showed six pairs of nerve cords radiating from the brain and forming a typical radial network pattern for the group (Koopowitz, 1973). The first two pairs are directed forward (anterior and anterior dorsal nerves), the third and fourth pairs (lateral and lateral dorsal nerves) are directed laterally from the brain, and the last two pairs (posterior and posterior dorsal nerves) are directed posteriorly. These nerves soon branch repeatedly towards the margin, becoming more delicate and forming anastomosing plexi that contain multi- and bipolar neurons (Koopowitz, 1974, 1986).

Neuroactive molecules can be classified broadly into neurotransmitters (e.g., acetylcholine, serotonin (5-HT), GABA, histamine), neuropeptides (e.g., FMRF-amide) and nitric oxide, a dissolved gas with nervous and endocrine function. In flatworms, immunocytochemistry (ICC) has demonstrated the presence of several neuroactive molecules, including typical neurotransmitters, nitric oxide synthase, and also a number of regulatory neuropeptides (Reuter and Halton, 2001). Among the neuropeptides, four native flatworm FMRFamide-related peptides have been described (FaRPs), plus two neuropeptide F substances (Maule et al., 1993, Johnston et al., 1996). The specific role of neuropeptides is still unclear although a myoexitatory function is likely (Day et al., 1997; Marks et al., 1996, Monneypenny et al., 1997).

Serotonin appears to be the most common biogenic amine in all platyhelminth taxa examined to date. Macrostomids (Microstomum Schmidt, 1848, Macrostomum 
Schmidt, 1848), triclads (Dendrocoelum Ørsted, 1844, Polycelis Eherenberg, 1831), and catenulids (Stenostomum Schmidt, 1848) all exhibit immunoreactivity to serotonin, as do representatives of monogeneans, trematodes, and cestodes (Wikgren and Reuter, 1985; Reuter, 1988; Reuter et al., 1986, 1996; Ladurner et al., 1997). Functionally, serotonin is an excitatory neurotransmitter stimulating muscle contraction and it also plays a role in controlling growth, asexual reproduction and regeneration (Villar and Schaeffer, 1993). Serotonin immunoreactivity has been shown in the submuscular and subepidermal plexi, in the main nerve cords (Reuter et al., 1995), and in positive fibers that encircle the pharynx. Nerve fibers but no cell bodies have been visualized in the peripheral nervous system (Reuter et al., 1986). In general, the distribution pattern of serotonin is distinct from cholinergic and peptidergic pathways, however, it parallels catecholamine staining patterns (Shishov, 1991).

Serotonin and FMRFamide related peptides (FaRPs) play important roles in myoexcitatory activities, including motility of the gut and pharynx related to feeding behavior (Forest and Lindsay, 2008), or in the contraction of locomotory muscles of different species of Platyhelminthes (Mousley et al., 2005, Cebrià, 2008, Kreshchenko and Tolstenkov, 2012). In the freshwater planarian Schmidtea mediterranea Benazzi et al., 1975, both, the CNS and PNS assemble a loose 5-HT nerve network that is expressed throughout the animal from head to tail (Cebrià, 2008). Furthermore, FMRFamide was expressed in both the CNS and PNS of the turbellarian species Polycelis tenuis Ijima, 1884, and Girardia tigrina Girard, 1850 (Kreshchenko and Tolstenkov, 2012). Although both of these two neurotransmitters may be expressed throughout the nervous systems of flatworms, they often show distinctively different staining patterns. For example, in the basal platyhelminth Macrostomum lignano Ladurner, et al., 2005, serotonergic nerve cells are densely clustered in the pharyngeal region and are relatively sparse in the brain neuropile, whereas FMRFaminergic cells are concentrated in ventro-lateral and centro-lateral compartments of the brain neuropile (Morris et al., 2007).

Hence, the major goals of our study were to compare the gross and fine morphology of the CNS of 12 different polyclad species at the light-microscopic level, to examine serotonin (5-HT) and FMRFamide expression in the nervous system of Boninia divae Marcus and Marcus, 1968 using immunocytochemistry (ICC), and to review our results in light of the newest phylogenetic understanding of platyhelminth relationships (Laumer and Giribet, 2014; Egger et al., 2015; Laumer et al., 2015) in an attempt to place the diversity of flatworm nervous systems into an evolutionary context.

\section{Materials and Methods}

\section{Animals}

Specimens representing 12 species of polyclads were collected from different sites in the Caribbean. In addition, a deep-sea specimen of Anocellidus profundus Quiroga, Bolaños and Litvaitis, 2006, from the North Pacific was also included in the analysis (specimen courtesy of Dr. Janet Voight, Field Museum of Natural History, Chicago, Illinois, USA). For details of collection, fixation, and species identification see Litvaitis et al. (2010).

\section{Histological studies of polyclad nervous systems}

A specimen of each species was embedded in paraffin in its entirety, longitudinally sectioned at $7-10 \mu \mathrm{m}$, and stained with Milligan Trichrome technique which allows differentiating well among connective tissue, muscles, and nervous fibers (Presnell and Schreibman, 1997). Additional cross and sagittal sections were also prepared. De-paraffinized sections were treated with $3 \%$ potassium dichromate-hydrochloric acid solution for 5 min. Following a distilled water rinse, sections were stained in acid fuchsin for $8 \mathrm{~min}$. After a second distilled water rinse, they were placed into $1 \%$ phosphomolybdic acid for 2 min and then stained with $2 \%$ solution of Orange $\mathrm{G}$ for $5 \mathrm{~min}$. After a final rinse with distilled water, the sections were treated with $1 \%$ hydrochloric acid solution for 2 min stained in Fast Green for $8 \mathrm{~min}$, treated with $1 \%$ acetic acid for $3 \mathrm{~min}$ and then rinsed in 95\% alcohol and dehydrated. Finally, the sections were cleared with Histoclear (National Diagnostics) and mounted in Permount (Fisher Scientific). Slides were observed and photographed under an Axiostar Plus (Zeiss, Thornwood, New York) light microscope. We applied the morphological criteria of Reuter et al. (1998) to distinguish main nerve cords from secondary nerve cords for the examination of the NS. Cross and sagittal sections were used for interpretation. In addition, whole mounts of all species were prepared, by dehydrating the specimens in a graded alcohol series, cleared with Histoclear, and mounted in Permount.

\section{Immunocytochemistry (ICC) in Boninia divae}

Boninia divae specimens were anaesthetized with 7.14\% magnesium chloride hexahydrate before fixation with freshly made $4 \%$ paraformaldehyde for $4 \mathrm{~h}$ at $4{ }^{\circ} \mathrm{C}$. Then the specimens were washed in BSA-T: PBS-T (PBS containing $0.3 \%$ Triton $\mathrm{X} 100$ ) + BSA $1 \%$. Overnight bleaching with light was carried out with $6 \% \mathrm{H}_{2} \mathrm{O}_{2}$ in methanol. Samples were washed six times in BSA-T. We used the following primary antibodies: anti-serotonin (rabbit anti-Serotonin, cat. no. 18-0077, Invitrogen) diluted 1:1000 in BSA-T, and rabbit anti-FMRFamide polyclonal antibody at 1:1000. The former antibody was used previously in the freshwater planarian S. mediterranea (Cebrià, 2008), and the latter was kindly provided by B. Egger (University 
College London). After incubation for $72 \mathrm{~h}$ at $4{ }^{\circ} \mathrm{C}$ in the primary antibody, the samples were washed again six times in BSA-T. Next, the following secondary antibodies were used: goat anti-rabbit conjugated to Alexa Fluor 555 (Invitrogen, Life Technologies), and goat anti-mouse conjugated to Alexa Fluor 488 (Invitrogen, Life Technologies) respectively. After the samples were incubated in the secondary antibodies for $48 \mathrm{~h}$ at $4{ }^{\circ} \mathrm{C}$, samples were washed six times and mounted in PBS-glycerol 1:9. Fluorescence microscopy was performed with a Nikon Eclipse Ti (USA). Four replicates were used for each antibody treatment.

\section{Results}

\section{Gross morphology of the polyclad nervous system}

The overall arrangement of the nervous system in polyclad flatworms consists of an anterior encapsulated bilobed brain from which six pairs of nerve cords extend in different directions, and an extensive network of longitudinal and transverse nerves that intersect at right angles to form a highly stereotypical orthogonal pattern. Two main ventral thick nerve cords were consistently present in all examined species. These always extended posteriorly, whereas most other nerve cords were radially distributed in the anterior part of the animal. Several thinner commissures of different arrangements connected the major nerve cords. A dorsal diffuse nerve net was found in most species examined.

We observed three distinct organizations for the polyclad CNS (Categories I-III). These were based on the position of the brain, the thickness of the main nerve cords, the shape of the cords in cross sections, the number and position of the nerve cords in the body, and the tissue surrounding the nerve cords.

\section{Category I central nervous system}

Species in this category (Table 1) showed: (a) large encapsulated brains (Figure 1A, B), (b) thick main nerve cords that were dorsoventrally flattened and completely submerged into the parenchyma (Figure 1B), and (c) welldefined globuli cell masses (Figure 1C, D). With one exception (i.e. Pericelis cata), the species in this category are all acotyleans (Table 1): Styloplanocera fasciata (Schmarda, 1859) (Gnesioceridae), Melloplana ferruginea (Schmarda, 1859) (Pleioplanidae), Armatoplana lactoalba (Verrill, 1900) (Stylochoplanidae), Phaenocelis medvedica Marcus, 1952 (Cryptocelidae), Anocellidus profundus (Anocellidae), Idioplana atlantica Bock, 1913 (Pseudostylochidae).

Here we use Styloplanocera fasciata as the representative species to describe the Category I CNS. The CNS was submerged in the parenchyma. The cerebral ganglion was enclosed by a capsule (Figure 1B), and was located between the tentacles at about $1 / 5$ to $1 / 6$ of the total body length from the anterior margin. A dorsal view of whole
A
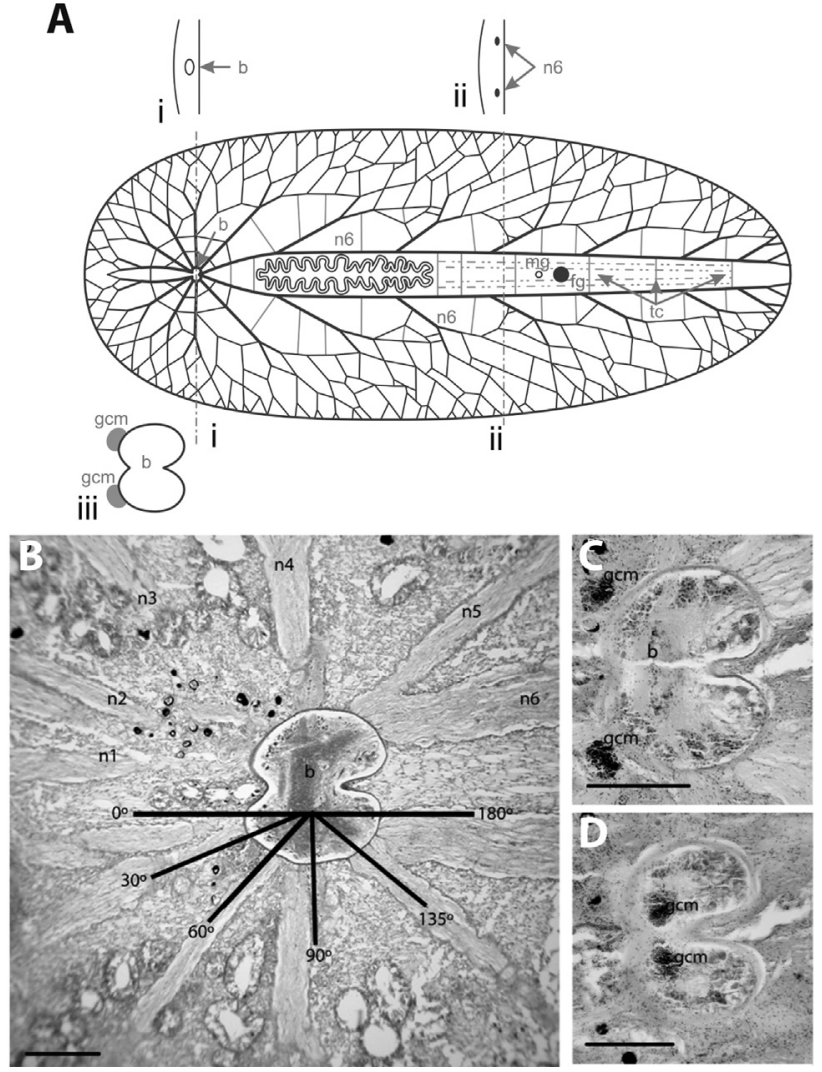

Figure 1 - Polyclad nervous system organization: Category I. A. Schematic representation includes cross sections at the level of the brain (i) and at the level of the $\mathrm{n} 6$ nerve pair (ii); detail of the brain is shown below (iii) B. Longitudinal section through the anterior region of Styloplanocera fasciata showing the distribution of the ventral nerve cords. Scale bar 250 $\mu \mathrm{m}$. C. Section through the ventral region of the $S$. fasciata brain, showing the external globuli cell masses. Scale bar $250 \mu \mathrm{m}$. D. Section through the dorsal region of the $S$. fasciata brain, showing the internal globuli cell masses. Scale bar $250 \mu \mathrm{m}$. b brain, fg female gonopore, gcm globuli cell masses, $\mathrm{mg}$ male gonopore, $\mathrm{n}$ nerve cords, $\mathrm{n} 6$ major nerve cords, tc transverse commissures.

mounts and longitudinal sections revealed very conspicuous depressions, which divide the brain into two lobes. The posterior depression was deeper than the anterior one (Figure 1B-D). The brain was dorsoventrally flattened, and in mature ( $24 \mathrm{~mm}$ long) preserved specimens it was about $525 \mu \mathrm{m}$ wide, $475 \mu \mathrm{m}$ long and $275 \mu \mathrm{m}$ tall.

Six pairs of nerve cords covered by a sheath were found to branch out from the brain capsule (Figure 1A,B). The brain capsule did not extend along the branches; rather it appeared that the nerve cords perforated the capsule. The first four pairs innervated the region of the animal anterior to the brain in a well-defined radial pattern with respect to the longitudinal axis of the worm: $\mathrm{n} 1$ at $0^{\circ}, \mathrm{n} 2$ at $30^{\circ}, \mathrm{n} 3$ at $60^{\circ}$, and $\mathrm{n} 4$ at $90^{\circ}$; and the last two pairs $(\mathrm{n} 5, \mathrm{n} 6)$ innervated the posterior region of the body in angles of approximately $135^{\circ}$ and $180^{\circ}$, respectively (Figure 1B). Some nerve cords (n1/n2 and n5/n6) shared roots, whereas others (n3 and n4) did not share the same root but attached very close to each 
Table 1 - Comparison of the nervous system in polyclads

\begin{tabular}{|c|c|c|c|c|c|}
\hline $\begin{array}{l}\text { Family } \\
\text { (in alphabetical order) }\end{array}$ & Species (in alphabetical order) & Globuli cell masses & Brain & Main nerve cords & CNS category \\
\hline \multicolumn{6}{|l|}{ Acotylea: } \\
\hline Anocellidae & $\begin{array}{l}\text { Anocellidus profundus Quiro- } \\
\text { ga, Bolanos \& Litvaitis, 2006* }\end{array}$ & $\begin{array}{l}\text { Well-developed, } \\
\text { paired }\end{array}$ & $\begin{array}{l}\text { Large, bilobed, with } \\
\text { capsule }\end{array}$ & $\begin{array}{l}\text { Thick, dorso-ventrally } \\
\text { flattened, well-developed }\end{array}$ & I \\
\hline Callioplanidae & $\begin{array}{l}\text { Trigonoporus cephalophthalmus } \\
\text { Lang, } 1884\end{array}$ & Not described & $\begin{array}{l}\text { Large, bilobed } \\
\text { (Lang, 1884) }\end{array}$ & Not described & $?$ \\
\hline Cestoplanidae & $\begin{array}{l}\text { Cestoplana faraglionensis } \\
\text { Lang, } 1884\end{array}$ & Not described & $\begin{array}{l}\text { Large, bilobed, with } \\
\text { capsule (Lang, 1884) }\end{array}$ & $\begin{array}{l}\text { Thick, dorso-ventrally } \\
\text { flattened, well-developed } \\
\text { (Lang, 1884) }\end{array}$ & III? \\
\hline Cryptocelidae & $\begin{array}{l}\text { Phaenocelis medvedica Mar- } \\
\text { cus, } 1952^{*}\end{array}$ & $\begin{array}{l}\text { Well-developed, } \\
\text { paired }\end{array}$ & $\begin{array}{l}\text { Large, bilobed, with } \\
\text { capsule }\end{array}$ & $\begin{array}{l}\text { Thick, dorso-ventrally } \\
\text { flattened, well-developed }\end{array}$ & I \\
\hline Gnesioceridae & $\begin{array}{l}\text { Styloplanocera fasciata (Schmar- } \\
\text { da, 1859)* }\end{array}$ & $\begin{array}{l}\text { Well-developed, } \\
\text { paired }\end{array}$ & $\begin{array}{l}\text { Large, bilobed, with } \\
\text { capsule }\end{array}$ & $\begin{array}{l}\text { Thick, dorso-ventrally } \\
\text { flattened, well-developed }\end{array}$ & I \\
\hline \multirow[t]{2}{*}{ Leptoplanidae } & $\begin{array}{l}\text { Discocelis tigrina } \\
\text { (Blanchard, 1847) }\end{array}$ & Not described & $\begin{array}{l}\text { Large, bilobed, with } \\
\text { capsule (Lang, 1884) }\end{array}$ & Not described & $\mathrm{I} ?$ \\
\hline & $\begin{array}{l}\text { Leptoplana tremellaris (Müller } \\
\text { OF, 1773) }\end{array}$ & $\begin{array}{l}\text { Well-developed, } \\
\text { paired (Lang, 1884) }\end{array}$ & $\begin{array}{l}\text { Large, bilobed, with } \\
\text { capsule (Lang, 1884) }\end{array}$ & $\begin{array}{l}\text { Thick, dorso-ventrally } \\
\text { flattened, well-developed } \\
\text { (Lang, 1884) }\end{array}$ & $\mathrm{I} ?$ \\
\hline Planoceridae & Planocera graffi Lang, 1879 & $\begin{array}{l}\text { Well-developed, } \\
\text { paired (Lang, 1884) }\end{array}$ & $\begin{array}{l}\text { Large, slightly } \\
\text { bilobed, with capsule } \\
\text { (Lang, 1884) }\end{array}$ & $\begin{array}{l}\text { Thick, dorso-ventrally } \\
\text { flattened, well-developed } \\
\text { (Lang, 1884) }\end{array}$ & $\mathrm{I} ?$ \\
\hline Pseudostylochidae & Idioplana atlantica Bock, 1913* & $\begin{array}{l}\text { Well-developed, } \\
\text { paired }\end{array}$ & $\begin{array}{l}\text { Large, bilobed, with } \\
\text { capsule }\end{array}$ & $\begin{array}{l}\text { Thick, dorso-ventrally } \\
\text { flattened, well-developed }\end{array}$ & I \\
\hline Pleioplanidae & $\begin{array}{l}\text { Melloplana ferruginea (Schmar- } \\
\text { da, 1859)* }\end{array}$ & $\begin{array}{l}\text { Well-developed, } \\
\text { paired }\end{array}$ & $\begin{array}{l}\text { Large, bilobed, with } \\
\text { capsule }\end{array}$ & $\begin{array}{l}\text { Thick, dorso-ventrally } \\
\text { flattened, well-developed }\end{array}$ & I \\
\hline \multirow[t]{2}{*}{ Stylochoplanidae } & $\begin{array}{l}\text { Armatoplana lactoalba (Ver- } \\
\text { rill, 1900)* }\end{array}$ & $\begin{array}{l}\text { Well-developed, } \\
\text { paired }\end{array}$ & $\begin{array}{l}\text { Large, bilobed, with } \\
\text { capsule }\end{array}$ & $\begin{array}{l}\text { Thick, dorso-ventrally } \\
\text { flattened, well-developed }\end{array}$ & I \\
\hline & Comoplana agilis (Lang, 1884) & Not described & $\begin{array}{l}\text { Large, bilobed, with } \\
\text { capsule (Lang, 1884) }\end{array}$ & $\begin{array}{l}\text { Thick, dorso-ventrally } \\
\text { flattened, well-developed } \\
\text { (Lang, 1884) }\end{array}$ & $\mathrm{I} ?$ \\
\hline \multicolumn{6}{|l|}{ Cotylea: } \\
\hline Anonymidae & Anonymus virilis Lang, 1884 & Not described & $\begin{array}{l}\text { Large, bilobed, with } \\
\text { capsule (Lang, 1884) }\end{array}$ & $\begin{array}{l}\text { Thick, dorso-ventrally } \\
\text { flattened, well-developed } \\
\text { (Lang, 1884) }\end{array}$ & $?$ \\
\hline Boniniidae & $\begin{array}{l}\text { Boninia divae Marcus \& Mar- } \\
\text { cus, 1968* }\end{array}$ & Poorly defined & $\begin{array}{l}\text { Anteriorly located, } \\
\text { with capsule }\end{array}$ & $\begin{array}{l}\text { Thin, round, well- } \\
\text { developed }\end{array}$ & III \\
\hline \multirow[t]{6}{*}{ Euryleptidae } & $\begin{array}{l}\text { Cycloporus papillosus } \\
\text { (Sars, 1878) }\end{array}$ & Not described & $\begin{array}{l}\text { Large, bilobed, with } \\
\text { capsule (Lang, 1884) }\end{array}$ & Not described & II? \\
\hline & Eurylepta lobianchi (Lang, 1879) & Not described & $\begin{array}{l}\text { Large, bilobed, with } \\
\text { capsule (Lang, 1884) }\end{array}$ & Not described & II? \\
\hline & $\begin{array}{l}\text { Maritigrella crozieri } \\
\text { (Hyman, 1939)* }\end{array}$ & Poorly defined & $\begin{array}{l}\text { Small, slightly } \\
\text { bilobed }\end{array}$ & $\begin{array}{l}\text { Thin, dorso-ventrally flat- } \\
\text { tened }\end{array}$ & II \\
\hline & $\begin{array}{l}\text { Oligocladus sanguinolentus } \\
\text { Lang, } 1884\end{array}$ & Not described & $\begin{array}{l}\text { Anteriorly lo- } \\
\text { cated, Large, bilobed, } \\
\text { with capsule } \\
\text { (Lang, 1884) }\end{array}$ & Not described & II? \\
\hline & $\begin{array}{l}\text { Prostheceraeus vittatus } \\
\text { (Montagu, 1815) }\end{array}$ & Not described & $\begin{array}{l}\text { Large, bilobed, with } \\
\text { capsule (Lang, 1884) }\end{array}$ & Not described & II? \\
\hline & $\begin{array}{l}\text { Stylostomum ellipse } \\
\text { (Dalyell, 1853) }\end{array}$ & Not described & $\begin{array}{l}\text { Large, bilobed, with } \\
\text { capsule (Lang, 1884) }\end{array}$ & Not described & II? \\
\hline Pericelidae & $\begin{array}{l}\text { Pericelis cata Marcus \& } \\
\text { Marcus, 1968* }\end{array}$ & $\begin{array}{l}\text { Well-developed, two } \\
\text { pairs }\end{array}$ & $\begin{array}{l}\text { Large, bilobed, with } \\
\text { capsule }\end{array}$ & $\begin{array}{l}\text { Thick, dorso-ventrally } \\
\text { flattened, well-developed }\end{array}$ & I \\
\hline Prosthiostomidae & $\begin{array}{l}\text { Enchiridium periommatum } \\
\text { Bock, 1913* }\end{array}$ & Poorly defined & $\begin{array}{l}\text { Small, slightly } \\
\text { bilobed, no capsule }\end{array}$ & $\begin{array}{l}\text { Thin, dorso-ventrally flat- } \\
\text { tened }\end{array}$ & II \\
\hline
\end{tabular}


Table 1 (cont.)

\begin{tabular}{lllll}
\hline $\begin{array}{l}\text { Family } \\
\text { (in alphabetical order) }\end{array}$ & Species (in alphabetical order) & Globuli cell masses & Brain & Main nerve cords \\
\hline & $\begin{array}{l}\text { Prosthiostomum siphunculus } \\
\text { (Della Chiaje, 1822) }\end{array}$ & Not described & $\begin{array}{l}\text { Large, bilobed, with } \\
\text { capsule (Lang, 1884) }\end{array}$ & Not described \\
Pseudocerotidae & $\begin{array}{l}\text { Pseudoceros bicolor } \\
\text { Verrill, 1902* }\end{array}$ & Absent & $\begin{array}{l}\text { Small, round, not } \\
\text { bilobed }\end{array}$ & $\begin{array}{l}\text { Thin, dorso-ventrally flat- } \\
\text { tened }\end{array}$ \\
& $\begin{array}{l}\text { Pseudoceros bolool Newman \& } \\
\text { Cannon, 1994* }\end{array}$ & Absent & $\begin{array}{l}\text { Small, round, not } \\
\text { bilobed }\end{array}$ & $\begin{array}{l}\text { Thin, dorso-ventrally flat- } \\
\text { tened }\end{array}$ \\
& $\begin{array}{l}\text { Thysanozoon brocchii } \\
\text { (Risso, 1818) }\end{array}$ & $\begin{array}{l}\text { Poorly defined } \\
\text { (Lang, 1884) }\end{array}$ & $\begin{array}{l}\text { Small, round, not } \\
\text { bilobed (Lang, 1884) }\end{array}$ & $\begin{array}{l}\text { Thin, dorso-ventrally flat- } \\
\text { tened (Lang, 1884) }\end{array}$ \\
\hline
\end{tabular}

*Examined in this study.

other in the brain (Figure 1B). Transverse commissures formed connections between the radial nerve cords (Figure 1A). More distant from the brain, the nerve cords of the first four pairs subdivided into dichotomous branches toward the margin, where they became thinner and connected with other nerve fibers originating from the proximal nerve cords. Thus, these nerve fibers formed polygons, and divided into a complex marginal net (Figure 1A). Cord pairs $\mathrm{n} 5$ and $\mathrm{n} 6$ innervated the region of the worm posterior to the brain. Pair $n 5$ divided into dichotomous branches innervating the region from the level of the brain to the middle of the pharynx, and pair n6 started dividing where the pharynx began, innervating the remainder of the animal (Figure $1 \mathrm{~A}$ ). The number of main cords leaving the brain was constant in all the species analyzed within this category, although the degree of branching was variable. All nerve cords were dorsoventrally flattened and in transverse sections, appeared oval (Figure 1A). The nerve cords of the $\mathrm{n} 6$ pair were the thickest ones with a diameter of about $250 \mu \mathrm{m}$, identifying them as the main nerve cords for species in this category. The diameters of the remaining nerve cords varied from $125 \mu \mathrm{m}$ to $225 \mu \mathrm{m}$. Pair n6 extended the entire length of the worm, lying parallel on either side of the pharynx and becoming thinner posteriorly (Figure 1A). Along their lengths, the two nerve cords were connected by transverse commissures and eventually, they divided into very thin branches, forming different plexi, such as the pharyngeal and reproductive plexi (Figure 1A).

Anterior to the brain was a pair of globuli cell masses (Figure 1C); This characteristic feature was common to all species in the category, except for Pericelis cata, in which four well-developed globuli cell masses were located (above the roots of $n 2, n 3$, and n4). Distinctive from other species in the category that showed globuli cell masses only external to the brain capsule, S. fasciata globuli cell masses were located both external to the capsule on the ventral side right between the roots of nerve cord pairs $\mathrm{n} 2$ and $\mathrm{n} 3$ (Figure 1C), and dorsally in the interior of the capsule (Figure 1D).

\section{Category II central nervous system}

Species in this category (Table 1) showed: (a) slightly or not bilobed small brains (Figure 2), (b) thin main nerve cords that were dorsoventrally flattened and submerged in the parenchyma (Figure 2A, B), and (c) poorly defined globuli cell masses (Figure 2A-C, F, G) or the complete absence of globuli cell masses. All species in this category belonged to the suborder Cotylea (Table 1): Enchiridium periommatum (Prosthiostomidae), Pseudoceros bolool, P. bicolor (Pseudocerotidae), and Maritigrella crozieri (Euryleptidae). In this category, the cerebral eyes were located in the close vicinity of and/or above the brain (Figure 2D, E).

Here we use Enchiridium periommatum as the representative species to describe the Category II NS. The brain consisted of a complex of neurites and neuronal bodies enclosed by a thin capsule. It was anteriorly located, at about $1 / 8$ of the total length of the body. The cerebral eyes may be grouped into two clusters anterior to the brain as observed in this species (Figure 2D), but other species of this category may also present a single eye cluster directly above the brain (e.g. Pseudoceros bicolor, Figure 2E). The brain was only slightly bilobed with a shallow depression in the posterior (Figure 2A, B, D, F). However, in some species such as Pseudoceros bicolor (Figure 2E) and P. bolool (Figure $2 \mathrm{G}$ ) it was not bilobed. In a mature, preserved specimen of E. periommatum $(19 \mathrm{~mm} \times 9 \mathrm{~mm})$ the brain was about 550 $\mu \mathrm{m}$ wide, about $525 \mu \mathrm{m}$ long and about $300 \mu \mathrm{m}$ tall. All species in this category were characterized by having a small brain in relation to their body size when compared to species in Category I.

Six paired nerve cords radiated from the brain in $E$. periommatum at different angles from those in category I (Figure 2B). The main nerve cords apparently lacked the sheath observed in cords of Category I, or if such a sheath existed it was not well defined. Nerve cords (n1/n2 and $\mathrm{n} 5 / \mathrm{n} 6$ ) also shared roots as in S. fasciata (Category I), and the arrangement and dichotomous branching of the main nerve cords were basically the same. However, the ramifications had fewer transverse commissures connecting them (Figure 2A). The two main nerve cords (n6) had a diameter 
A

A $\quad \mid 0 \& b$

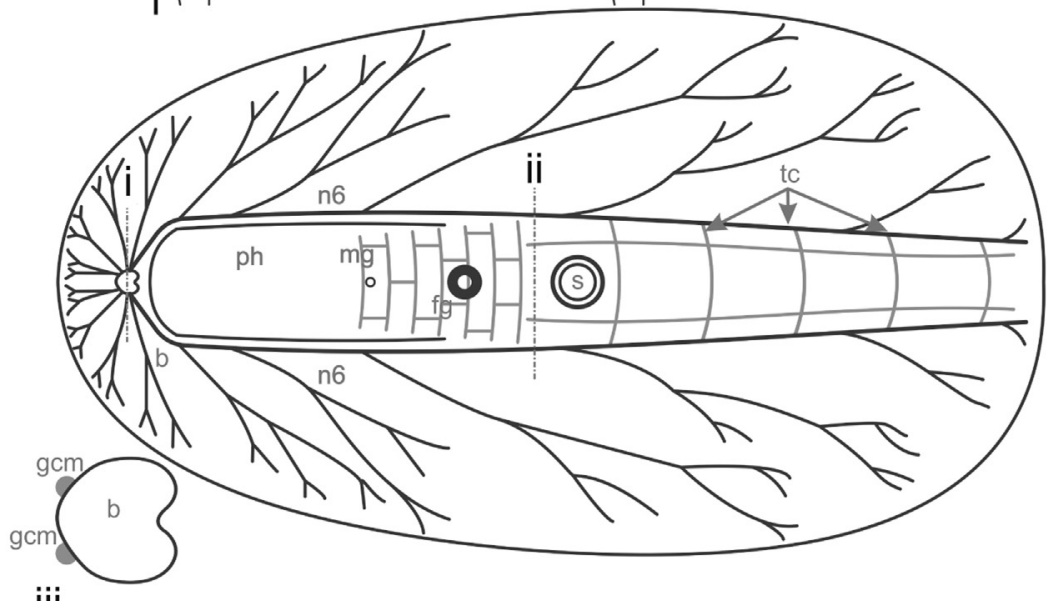

iii
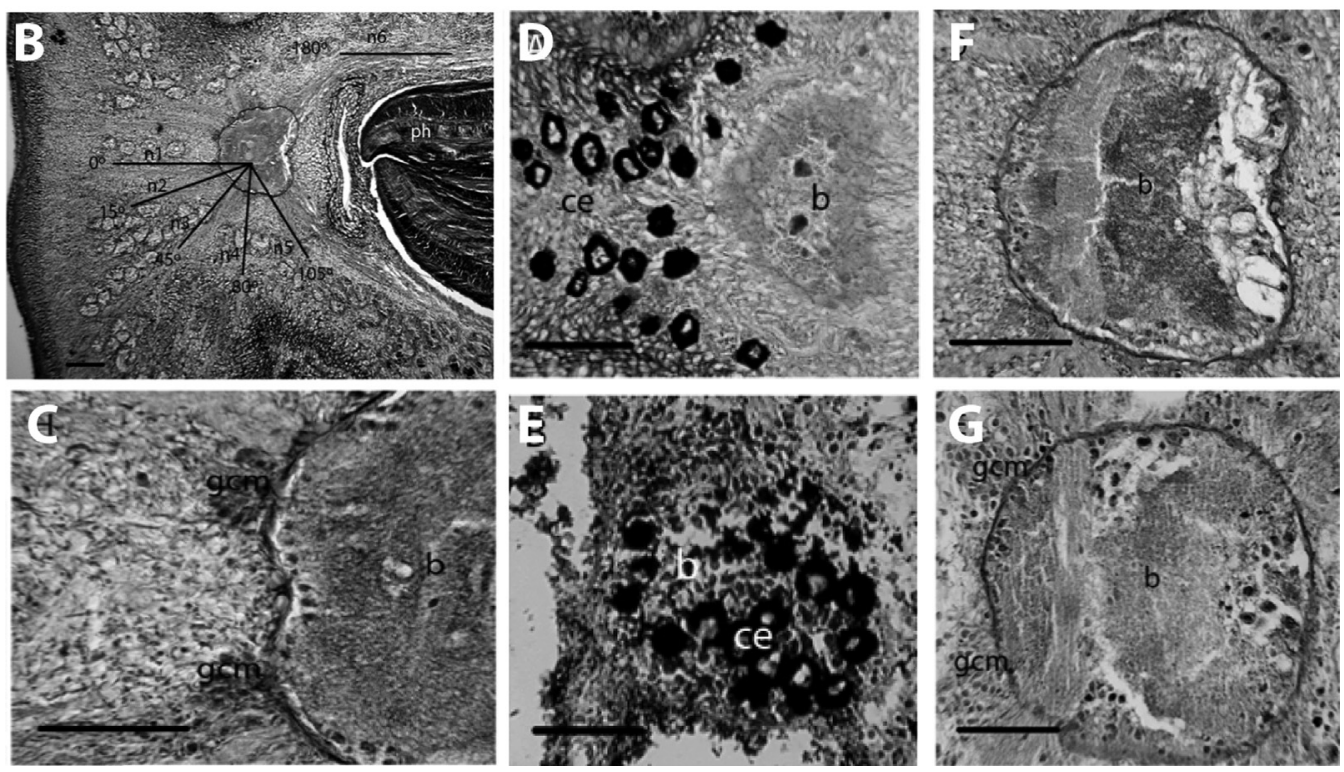

Figure 2 - Polyclad nervous system organization: Category II. A. Schematic representation includes cross sections at the level of the brain (i) and at the level of the $\mathrm{n} 6$ nerve pair (ii); detail of the brain is shown below (iii). B. Longitudinal section through the anterior region of Enchirium periommatum showing the distribution of the main ventral nerve cords. Scale bar $250 \mu \mathrm{m}$. C. Anterior portion of the E. periommatum brain, showing the poor development of the globuli cell masses. Scale bar $100 \mu \mathrm{m}$. D. Arrangement of the cerebral eyes in E. periommatum. Scale bar $100 \mu \mathrm{m}$. E. Arrangement of the cerebral eyes in Pseudoceros bicolor. Scale bar $100 \mu \mathrm{m}$. F. Brain shape in E. periommatum. Scale bar $100 \mu \mathrm{m}$. G. Brain shape in Pseudoceros bolool. b brain, fg female gonopore, gcm globuli cell masses, mg male gonopore, $\mathrm{n}$ nerve cords, n6 major nerve cords, ph pharynx, s sucker, tc transversal commissures.

of about $90 \mu \mathrm{m}$ and ran parallel to the pharynx. These were connected by thin transverse commissures along the entire length of the body. The diameters of the remaining nerves cords varied from $35 \mu \mathrm{m}$ to $70 \mu \mathrm{m}$.

The globuli cell masses were less defined than those in Category I. In most species, they consisted of few scattered cells above the roots of $\mathrm{n} 1$ and $\mathrm{n} 2$ cords (Figure 2C), and in Pseudocerotidae, globuli cell masses were completely absent (Figure 2G). No interior globuli cells masses were observed in any of the specimens examined.

\section{Category III central nervous system}

Species in this category (Table 1) showed: (a) a very anteriorly located brain (Figure 3A), (b) thick and round main nerve cords (Figure 3A), and (c) poorly defined globuli cell masses (Figure 3A, D). The sole species examined in this category (Boninia divae) belongs to the Boniniidae (Table 1), a family currently classified in the Cotylea. In this species, the ventral longitudinal musculature is extremely well-developed, and therefore the ventral nervous system of Boniniidae is completely submerged within the longitudinal muscles thus forming an intramus- 
A

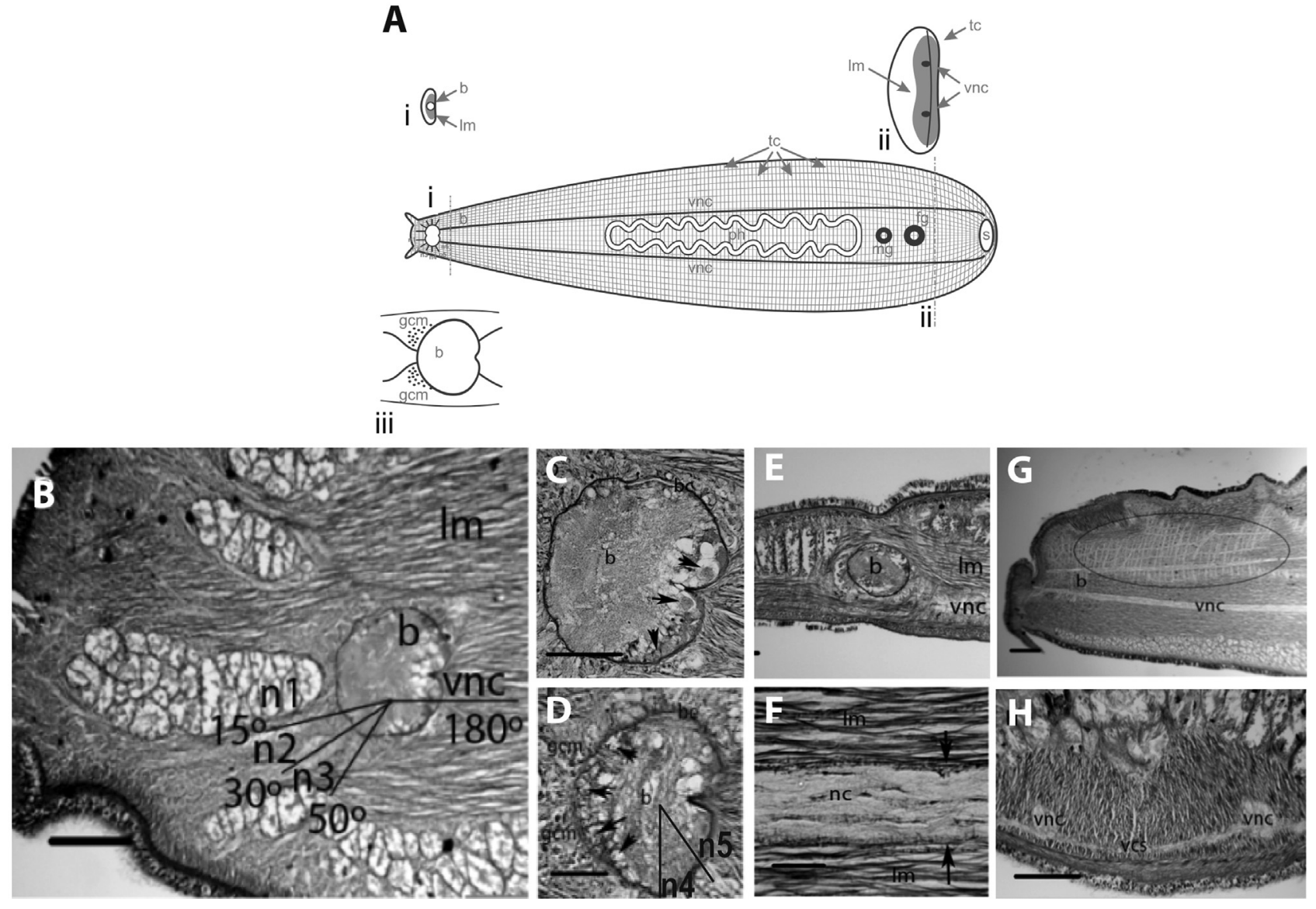

Figure 3 - Polyclad nervous system organization: Category III. A. Schematic representation includes cross sections at the level of the brain (i) and at the level of the 6 nerve pair (ii); detail of the brain is shown below (iii). B. Longitudinal section through the anterior region of Boninia divae, showing the distribution of the ventral nervous branches and immersion of entire nervous system into the longitudinal musculature. Scale bar $150 \mu \mathrm{m}$. C. Longitudinal section through the ventral region of the $B$. divae brain. Arrows indicate the Type I cells in the posterior portion of the brain. Scale bar $75 \mu \mathrm{m}$. D. Longitudinal section through the dorsal region of the $B$. divae brain. Arrows indicate Type III cells in the anterior portion of the brain. Notice that the globuli cell masses are formed by Type II cells that are poorly defined. Scale bar $75 \mu \mathrm{m}$. E. Sagittal section of the $B$. divae brain, showing longitudinal musculature surrounding the nervous system. Scale bar $150 \mu \mathrm{m}$. F. Sagittal section of the $B$. divae brain, showing a higher magnification through a ventral nerve cord submerged in longitudinal musculature. Notice that the nerve cord is surrounded by a thin sheath (arrows). Scale bar $100 \mu \mathrm{m}$. G. Anterior sagittal section showing the parallel branches and transverse commissures in B. divae, forming the orthogonal pattern (portion circled). Scale bar $250 \mu \mathrm{m}$. H. Cross section through a ventral commissure in $B$. divae. Scale bar $250 \mu \mathrm{m}$. b brain, fg female gonopore, gcm globuli cell masses, mg male gonopore, $\mathrm{n}$ nerve cords, n6 major nerve cords, ph pharynx, s sucker, tc transversal commissures.

cular plexus, in contrast to other rhabditophorans that generally show a submuscular plexus. Both, brain and main nerve cords in this category are submerged within the well-developed longitudinal body wall muscles (Figure 3B, E, F).

The well-defined brain capsule was about $175 \mu \mathrm{m}$ in diameter and was located very anteriorly at about $1 / 10$ in relation to the total body length. The brain was bilaterally symmetrical and had a slight depression on the posterior area (Figure 3C, D). It contained Type I cells (see below) in the posterior and ventral parts of the brain (Figure 3C), and Type III cells (see below) in the anterior and dorsal sides (Figure 3D). Type II cells were also found exterior to the brain, some of them scattered anterior to the brain, forming very rudimentary globuli cell masses (Figure 3D).
The round main pair of nerve cords (n6) ran along the entire length of the body, parallel to each side of the pharynx (Figure 3A). In a mature individual (18 $\mathrm{mm} \mathrm{x} 4 \mathrm{~mm}$ ), these measured about $100 \mu \mathrm{m}$ in diameter. The main nerve cords connected ventrally to the brain (Figure 3B, E), and branched radially (Figure 3A). There were no clear perforations of the brain capsule by these nerves cords. In addition to the main longitudinal cords, about 7 to 10 thinner cords ran parallel to them and all were connected by transverse commissures that crossed from one side of the body to the other (Figure 3A, G, H). This entire plexus formed a very consistent orthogonal pattern. At least three other pairs of nerve cords left the brain dorsally (not shown). These fibers subdivided into dichotomous branches, innervating the portion of the animal anterior to the brain, including the marginal tentacles. It is worthwhile to mention that a very 
diffuse, submuscular dorsal plexus was connected with the ventral plexus. A thin sheath was found covering all nerve cords in this category (Figure $3 \mathrm{~F}$ ).

\section{Polyclad brain cell types}

Within the encapsulated brains of all examined polyclads, we identified four cell types (Types I-IV) based on their histology. The four cell types observed in the brain of Styloplanocera fasciata are shown in Figure 4: Type I cells were large ganglion cells with big nuclei located in the posterior part of the brain (Figure 4A), Type II cells were globular cells which were characterized by a highly reduced cytoplasmic content and big nuclei rich in chromatin that occupied mostly the anterior rind of the brain and form the external globuli cell masses (Figure 4A), Type III cells were of medium size, and located mainly in the lateral parts along the periphery of the brain (Figure 4A), and Type IV cells were elongate and small, with sporadic occurrences along the nerve tracts, especially at bifurcations; a few were found in the posterior rind of the brain (Figure 4B).

\section{Serotonin and FMRFamide in Boninia divae}

Serotonin (Figure 5) was expressed in Boninia divae in the apical area of the nerve cords (Figure 5B), which form a U-shaped structure (U) and a concentric C-shaped structure $(\mathrm{C})$ anterior to the brain, along the main ventral nerve cords (Figure 5C), and in nerves associated with the sucker in the posterior of the animal (Figure 5D). Thinner longitudinal cords and the primary commissures that branched off from the main longitudinal cords showed a faint expression of serotonin (Figure 5B, 5C), whereas the brain was characterized by a complete lack of serotonin expression (Figure 5B).

The neuropeptide FMRFamide expression is shown in Figure 6. Apical to the brain, FMRFamide was expressed in the transverse commissures that form a ladder-like network, in the concentric $\mathrm{C}$-shaped structure (see above), and in nerve cords that extend into the tentacles (Figure 6B).

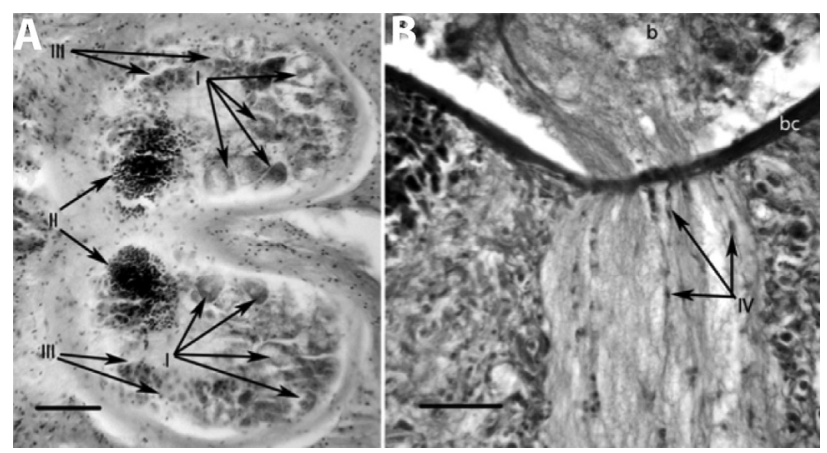

Figure 4 - Polyclad brain cell types. Longitudinal sections of the brain and nervous branches show distinguishable brain cells in Styloplanocera fasciata. A. Type I large ganglion cells with big nuclei; Type II globuli cells; Type III medium-sized cells. Scale bar $75 \mu \mathrm{m}$. B. Type IV small cells of elongated shape located along the nerve tracts. Scale bar $25 \mu \mathrm{m}$. b brain, bc brain capsule.
The brain also showed an absence of FMRFamide expression in this species (Figure 6B). FMRFamide expression was observed in all longitudinal nerve cords and transverse commissures (Figure 6C), forming the typical orthogonal pattern that is completely submerged within the longitudinal muscles. FMRFamide expression was particularly strong in nerve cells of the pharyngeal plexus (Figure 6C) and in the ventral nerve cords (Figure 6D). Posteriorly, FMRFamide positive nerve cells were also found in the nerve plexus that surrounds the sucker, with a lesser expression of in nerves directly associated with the sucker (Figure 6D).

Although some overlap of serotonin and FMRFamide expression was observed in the anterior of the animal, distinct patterns of expression were observed in posterior structures. In the head, serotonin and FMRFamide expression labeled the main and minor nerve cords, as well as the plexus innervating the tentacles. In addition, a bright and clear FMRFamide signal allowed observation of the main longitudinal ventral nerve cords, transverse commissures, and even thin nerves within the intramuscular plexus. In the posterior, seratonin primarily labeled the plexus of the sucker, whereas FMRFamide mostly labeled the pharyngeal plexus.

\section{Discussion}

\section{Evolution of the central nervous system in polyclads and the relevance of globuli cell masses}

The CNS of all polyclad species examined in this study display the same overall configuration described in earlier studies (Hadenfeldt, 1929; Hyman, 1951; Bullock and Horridge, 1965; Minichev and Pugovkin, 1979). An anterior encapsulated brain, six pairs of ventral nervous branches, and the typical radial pattern forming a network seem to be constant features.

Minichev and Pugovkin (1979) contended that the nervous system in polyclads was not homologous to that of other flatworms. Contrary to their assertion, we identified a pair of distinctly thicker nerve cords (n6) that originated from an anteriorly located brain in all polyclad species examined. The position, arrangement, and composition of these main nerve cords allow for homologizing of the polyclad CNS with the CNS of other flatworms. Specifically, the polyclad CNS corresponds to the typical orthogonal pattern common in other flatworms, in which two major longitudinal nerve cords are connected by transverse commissures at right angles in a ladder-like fashion (Reisinger, 1925; Bullock and Horridge, 1965; Reuter et al., 1998). Kotikova (1986) already supported the homology of the polyclad CNS to that of other Platyhelminthes, and proposed that the dorsoventral flattening and spreading out of the polyclad body plan was driving the evolution of the peculiar polyclad orthogon. 
A
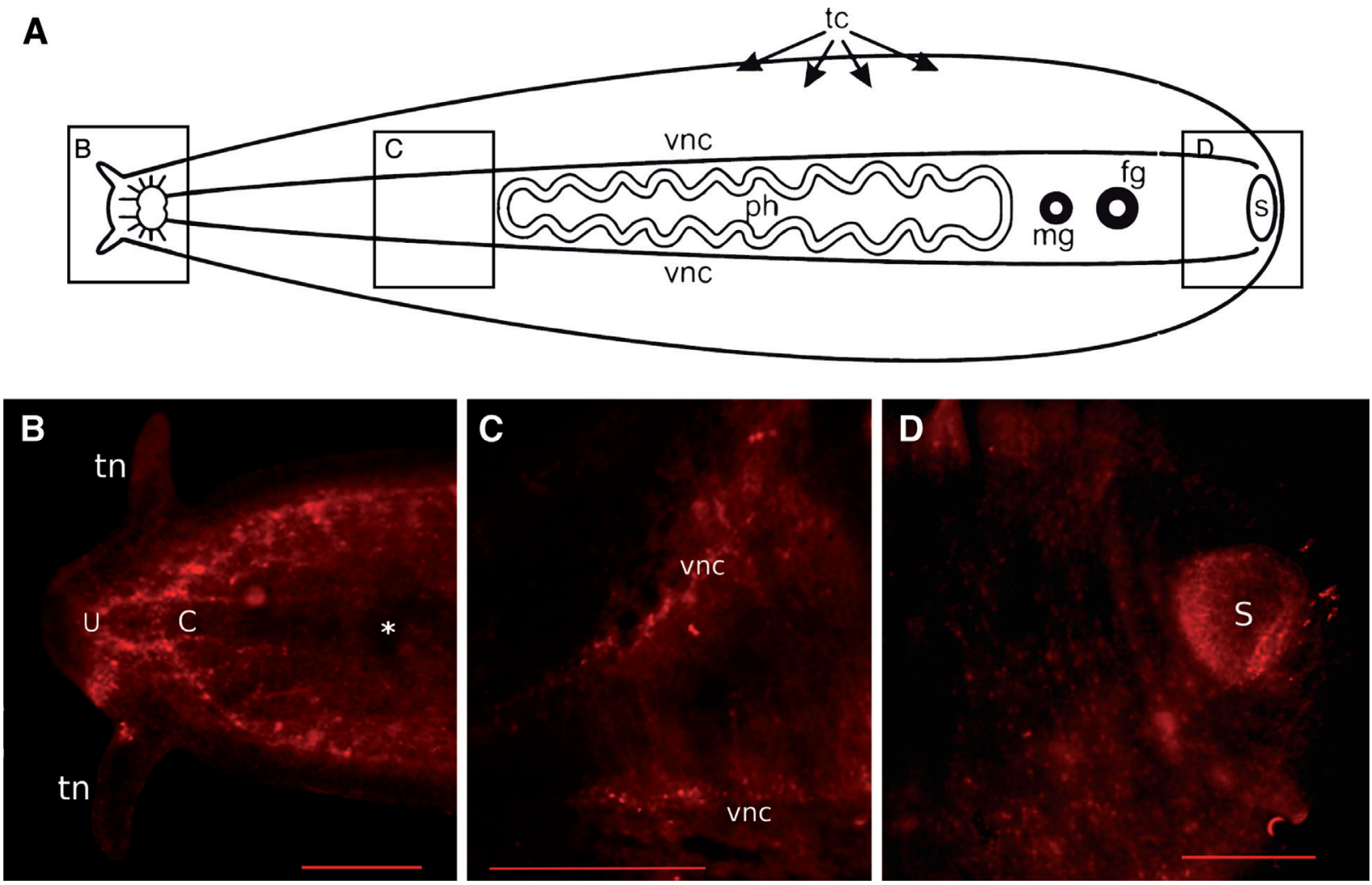

Figure 5 - Serotonin expressing neurons in Boninia divae (category III). A. Diagram of the nervous system indicates the sites shown in panels B-D. B. In the head, serotonin expression is observed in the anterior-most U-shaped nerves and anterior paired bilateral C-shaped nerve branches. Notice that no expression is observed in the brain. C. Serotonin expression in the ventral nerve cords. D. Serotonergic cells in the sucker. C C-shaped structure, vnc ventral nerve cords, s sucker, tn tentacle, ph pharynx, tc transverse commissures, U U-shaped structure; brain location denoted by asterisk. Scale bars $100 \mu \mathrm{m}$.

In our comparative study, we have noticed that the shape and position of the pharynx, in association with species-specific behaviors, may also influence polyclad features, such as the organization of the orthogon, thickness of the nerve cords, the position and size of the brain, or the presence of globuli cell masses. In general, acotyleans show centrally located pharynges and hence, the position of the brain is shifted further posterior from the anterior body margin. Acotylean brains are generally larger, have betterdeveloped external globuli cell masses, and the nerve cords are thicker, possibly indicating adaptive functions to a more complex neural integration, which may also be related to their generally more cryptic and benthic behaviors. In contrast, cotyleans show more anteriorly located pharynges displacing the brain to a more rostral position, closer to the anterior body margin.

Well-developed external globuli cell masses are the diagnostic characteristic of all acotylean polyclads examined in Category I. The cells are grouped in a cup-shaped fashion from which thin axons extend, forming a stalk that perforates the brain capsule. Similar structures have been found in nemerteans (Hanström, 1928), annelids including sipunculans (Golding, 1992; Åkesson, 1958), mollusks (Bullock and Horridge, 1965), and especially so in arthropods, where they are known as mushroom bodies
(Schürman, 1995; Strausfeld et al., 2006). The arthropod mushroom bodies are neuropiles of thin axons originating from clusters of small basophilic cells. They are part of the CNS and have been implicated in olfaction, learning, and memory (Strausfeld et al., 2006). The external globuli cell masses of all Category I species are morphologically similar in composition and position to the mushroom bodies of arthropods and annelids, which in turn, share similarities with the vertebrate pallium (Tomer et al., 2010). However, their function in polyclads remains unresolved. If the external globuli cell masses of acotyleans prove to be homologous to the mushroom bodies and the vertebrate pallium, then these structures may represent early sensory associative centers in the evolution of invertebrate nervous systems. However, further studies are needed to clarify the function of these structures and to establish homology.

Although slight differences in globuli cell masses can be distinguished among species of Category I, all acotyleans showed these prominent brain structures, which always formed mushroom-bodies. Even though Pericelis cata is currently classified into Cotylea, it was assigned to this category because its brain contains four external globuli cell masses that form mushroom-bodies. This may be indicative of a close relationship with acotyleans. Other characteristics of Pericelidae linking them to the Acotylea 

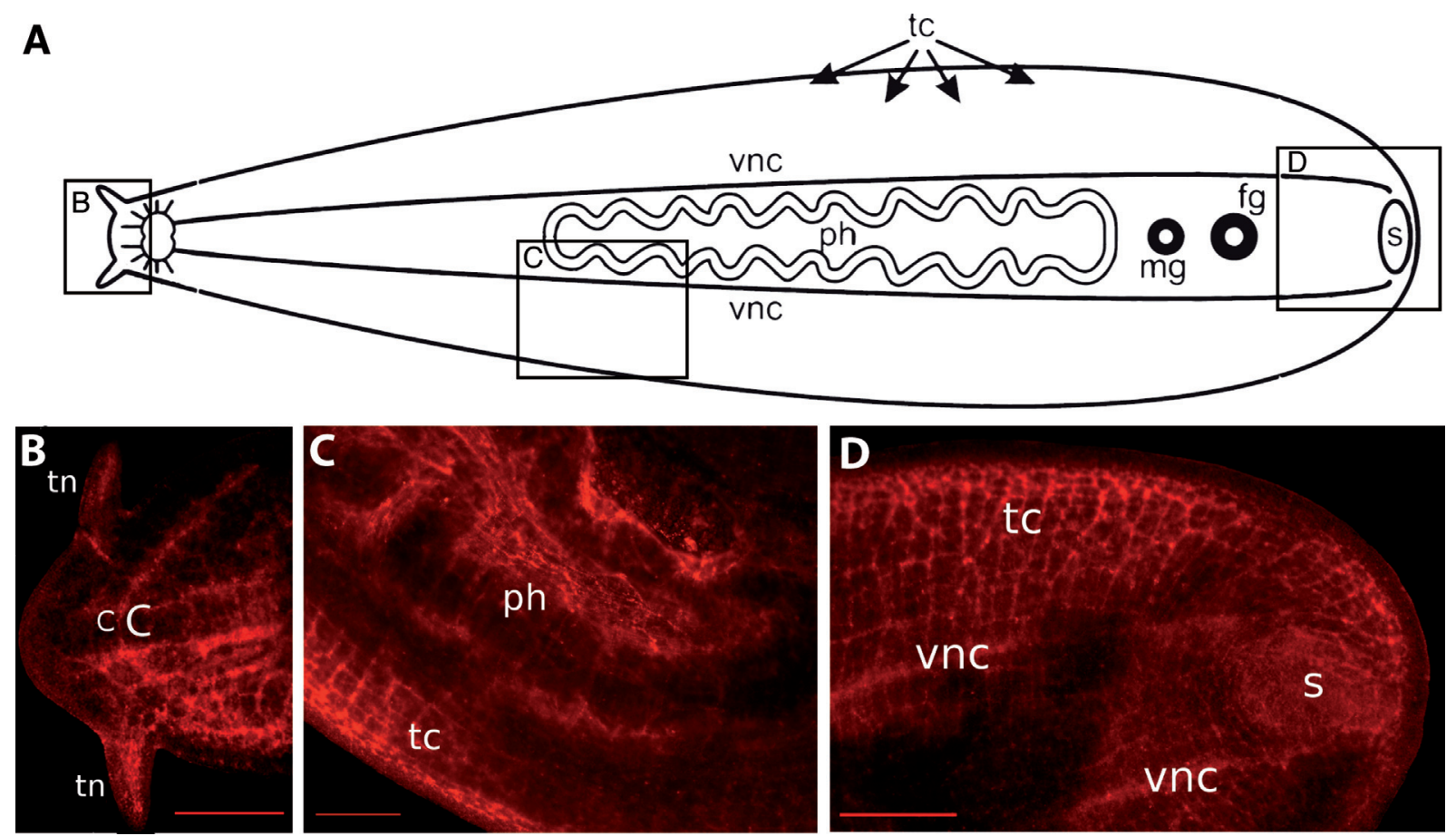

Figure 6 - FMRFamide expressing neurons in Boninia divae (category III). A. Diagram of the nervous system indicates the sites shown in panels B-D. B. In the head, FMRFamide expression is observed in the anterior paired bilateral C-shaped nerve branches and neurons that innervate the tentacles. Notice that no expression is observed in the brain. Scale bar $100 \mu \mathrm{m}$. C. FMRFamide expression in the pharyngeal plexus and in the submuscular plexus. Scale bar $200 \mu \mathrm{m}$ D. Mesh-like nerves surrounding the sucker also express FMRFamide. Scale bar $100 \mu \mathrm{m}$. C C-shaped structure, vnc ventral nerve cords, ph pharynx, tc transverse commissures, tn tentacle, s sucker.

include a centrally located ruffled pharynx, anteriorly directed uteri, and marginal eyes that surround the entire body. On the other hand, the presence of a ventral sucker, pseudotentacles, and uterine vesicles places the family into the Cotylea. A cladistic analysis of Cotylea resolved Pericelidae as a basal clade within the suborder and as sister group to another enigmatic polyclad family, the Boniniidae (Rawlinson and Litvaitis, 2008).

All other cotyleans examined in this study belong to our Category II, which is characterized by poorly developed (e.g., T. brocchii, see Lang, 1884) or absent globuli cell masses (e.g., P. bicolor, P. bolool, this study). Furthermore, globuli cell masses of this category never form mushroom-bodies. Finally, the position and size of our Type I brain cells appear to correspond well to the description of large ganglion cells in the posterior part of the T. brocchii brain (Lang, 1884). Although a functional correspondence remains to be established, we consider them homologous cells.

The phylogenetic position of Boniniidae is also controversial because it shares characteristics of cotyelans and acotyleans. Bock (1923) includes Boniniidae within Cotylea because of their marginal tentacles, the arrangements of the eyes, the sucker, and arrangement of uteri. Our study further supports Boniniidae as members of Cotylea because of their poorly defined globuli cell masses. However, further and more complete molecular phylogenetic studies with good taxon sampling of polyclad species are necessary to resolve this question.

\section{Neurons and behaviour in Boninia divae}

The particular fleshy consistency and elongated body shape of Boniniidae and their type of locomotion require special modifications of their nervous systems. Species in this group are commonly found under smoothsurfaced rocks in the supralitoral zones. Their movement is best described as "leech-like." Their ventral longitudinal musculature is extremely well developed, occupying almost half of the diameter of the worms. Although their CNS is still located ventrally, it is not submuscular as in other flatworms. Instead, the CNS of Boniniidae is completely submerged in the longitudinal musculature, thus forming an intramuscular plexus. Thus, the unique characteristics of the boniniid CNS may represent an autapomorphy of the family. However, the fact that Boninia divae exhibits an orthogonal pattern demonstrates that this configuration may represent a plesiomorphy, or has evolved independently in different groups as previously suggested by Kotikova $(1986,1991)$.

Serotonin and FMRFamide expression along the main ventral nerve cords of $B$. divae reveal their likely involvement in the regulation of motor neuron activities, as has been shown previously for other flatworms (Klagges et al., 1996, Moneypenny et al., 2001, Gustafsson et al., 
2002). Hence, it is possible that the close association between motor neurons and musculature in this species allows for a faster locomotory response mediated by serotonin and FMRFamide. Serotonin has also been reported to play important roles in muscular and sensory responses in polychaetes, and was found expressed in cells that innervate the somatic muscles (Golding, 1992).

Although a common and broad pattern of expression in the CNS of the worm is suggestive of relevant roles of both FMRFamide and serotonin for sensory and locomotory responses, only distinctive expression patterns allow for a predictive inference of these neuropeptides and the neurons expressing them. Because FMRFamide showed a relatively higher expression in nerve cells associated with the pharynx, we can predict that feeding or contractile pharyngeal action, sensory functions, absorption, secretion and/or digestion may be mediated by the FMRFaminergic system. Interestingly, FMRFamide has also been shown to regulate the motility of the digestive system in polychaetes (Krajniak and Greenberg, 1992) and the muscular contractions of the pharynx in leeches (O'Gara et al., 1999). In contrast, because serotonin showed a relatively greater expression in cells associated with the posterior sucker, we can predict that animal adhesion or posterior sucker action that operates the contraction and/or sensory response of this organ may be mediated preferentially by the serotonergic system. Expression of serotonin in the nerve plexus of the sucker has also been reported for cestodes (Webb and Mizukawa, 1985), and in a dense network of nerves at the tip of the tail of proseriates (Girstmair et al., 2014) and neodermatids (Biserova et al., 2000). Future studies are needed to test these hypotheses.

The brain of $B$. divae did not show any immunolabelling of either FMRFamide or serotonin. A recent publication describing the serotonergic system in Monocelis Eherenberg, 1831(Proseriata), which also has an encapsulated brain, only showed a faint immunosignal too in the brain (Girstmair et al., 2014). Electron microscopic studies in another polyclad Notoplana acticola revealed that most synaptic activity occurred in the rind of brain (Koopowitz, 1986), and therefore, the inner core of the brain may not be actively expressing neurotransmitters. In contrast, serotonergic immunoreactivity in the brain has been reported in flatworm species other than polyclads [e.g., Schmidtea mediterranea (Cebrià, 2008), Fasciola hepatica Linneaus, 1758 (Sukhdeo and Sukhdeo, 1988), Macrostomum juveniles (Morris et al., 2007) and Macrostomum adults (Egger et al., 2007)]. Low immunoreactivity for serotonin in the brain of $B$. divae may be due to the presence of atypical cells, or may in fact, represents a biologically sound level of serotonin release for polyclads. Alternatively, it is possible that either suboptimal technical conditions or a lower affinity of the antibody during the ICC may have generated the observed differences in expression signal. Additional neu- ral markers remain to be tested to further characterize polyclad brains.

\section{Evolution of the central nervous system in Platyhelminthes}

Trends that have been proposed for the evolution of the nervous system in flatworms include: (a) a transition from a diffuse nerve net of the bilaterian ancestor to the ventralized nervous system of protostomes (Lowe, et al., 2006); (b) reductions in the numbers of longitudinal cords (Reisinger, 1970, 1972); (c) a fusion of nerves of the subepidermal plexus to form longitudinal cords (Joffe and Reuter, 1993); (d) a conservation of the nervous circuits controlling the movement of the ciliated epidermis (Morris, 2007); (e) a transition from capsule-less brains in the ancestor to encapsulated brains (Kotikova and Raikova, 2008); and (f) a convergent evolution of glial cells in different platyhelminth groups (Radojcic and Pentreath, 1979; Hartenstein and Ehlers, 2000; Morris et al., 2004). To test these hypotheses, we used the most recent molecular phylogenies available for Platyhelminthes (Laumer and Giribet, 2014; Egger et al., 2015; Laumer et al., 2015), and mapped relevant characters of flatworm nervous systems onto it. Characters for the phylogenetic reconstruction (Figure 7) were obtained from published literature and from our current findings on polyclad nervous systems. In spite of the extensive literature on the topic, many groups remain poorly studied (Figure 7), including the Gnosonesimida, Bothrioplanida, Fecampiida, and Prolecithophora. In the following, we discuss whether each of the trends finds support based on our current understanding of flatworm nervous system evolution.

(a) A transition from a diffuse nerve net of the bilaterian ancestor to the ventralized nervous system of protostomes: Current phylogenies place Catenulida as the basal clade of Platyhelminthes. Although catenulids show a subepithelial, dispersed nerve network, a central nervous system develops by the presence of interconnected longitudinal cords (see cord-like orthogonal nervous system, Figure 7), and some species such as Catenula Duges, 1832 even show a regular configuration of the peripheral nervous system (Moraczewski et al., 1977). Studied species in all other platyhelminth groups show the well-defined central nervous system (i.e. orthogon) and a peripheral nervous system (Figure 7); thus, the prediction of an ancestor with a nerve net is not supported. However, proper outgroups remain to be analyzed comparatively.

(b) Reductions in the number of longitudinal cords: The reconstruction supports a reduction in the number of cords in several instances (see longitudinal cords, Figure 7). In the past, describing main cords in lateral, ventral, dorsal, ventro-lateral, dorso-lateral, or marginal positions generated much confusion. In contrast to earlier views (Reisinger, 1925) that include the brain and the orthogon in the definition of the turbellarian CNS, Reuter et al. (1998) 


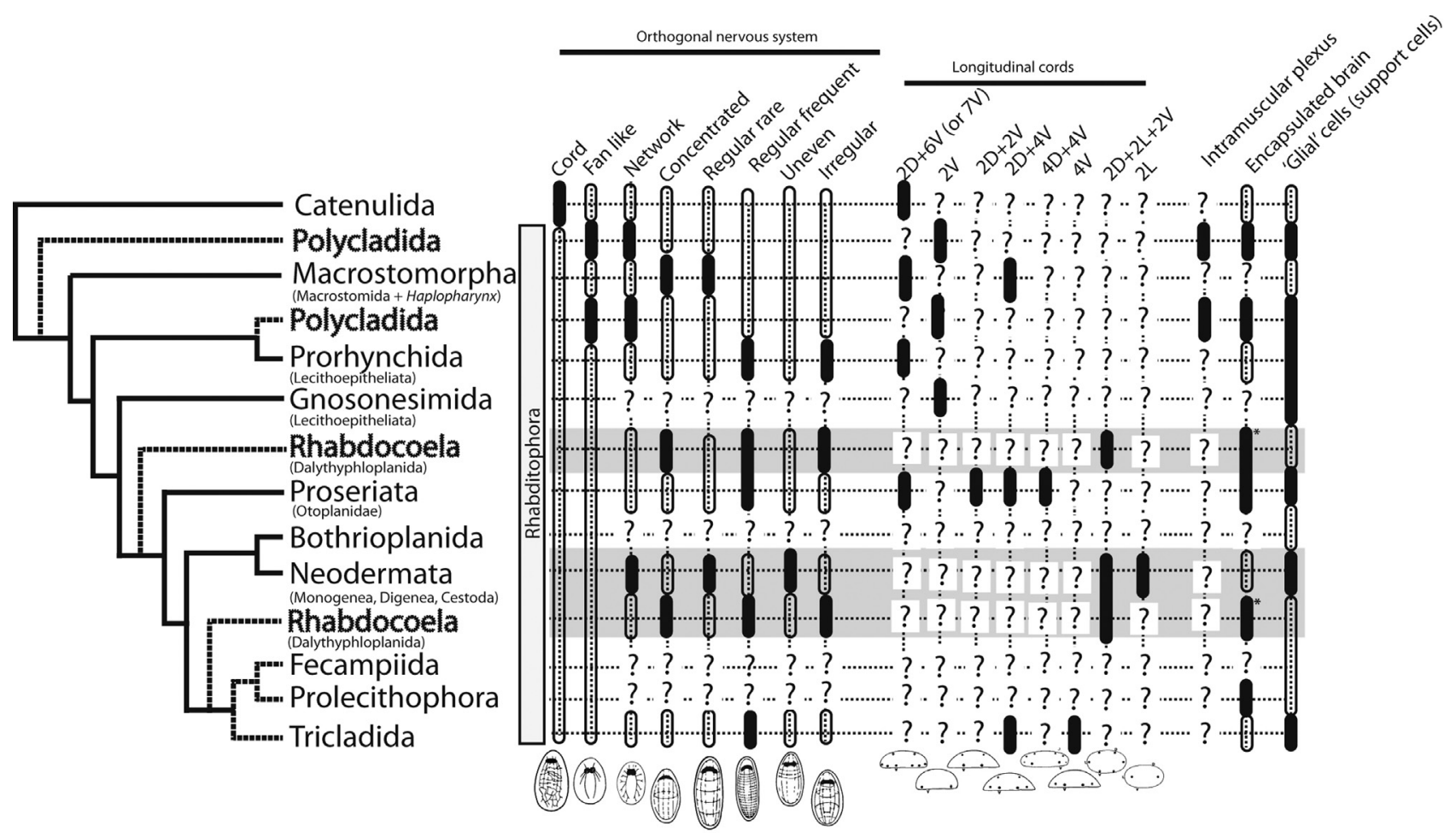

Figure 7 - Evolution of the nervous system in flatworms. Important characters/features of the nervous system of platyhelminths are reconstructed into most recent phylogenies (Laumer and Giribet, 2014; Laumer et al., 2015; Egger et al., 2015). Groups with conflicting phylogenetic positions are in dashes; and alternative positions are shown. Filled ellipses represent presence of the character, empty ellipses represent absence of the character, whereas question marks (?) represent lack of knowledge of the particular character for the group. Shaded box represent parasitic groups with the greatest diversity of orthogonal organization types. Cartoons were adapted from Reuter and Gustafsson (1995). References used in the reconstruction: Bailly et al. (2013); Bockerman et al. (1994); Fernandes et al. (2003); Hyman (1941, 1951); Mäntylä et al. (1998a, b); Karling (1968); Kotikova et al. (2002); Reisinger (1968); Reuter and Gustafsson (1995); Reuter et al. (1996); Rieger et al. (1991); Sluys (1989); Steinböck and Reisinger (1924); Steinböck (1927); Timoshkin (1991); Von Graff (1899). * Exception: no capsule was found in the rhabdocoel Strongylostoma simplex (Bedini and Lanfranchi, 1998).

only include the brain plus one pair of main nerve cords in their definition. Our current descriptions of the polyclad nervous systems also showed a pair of main cords in all examined species.

(c) A fusion of nerves of the subepidermal plexus to form longitudinal cords: This trend may actually explain the mechanism of the reduction of longitudinal cords discussed in (b).

(d) A conservation of the nervous circuits controlling the movement of the ciliated epidermis: The well-conserved flattened body plan of flatworms may impose certain developmental constraints onto the nervous system architecture and molecular circuitry that controls locomotion. To support this trend, the organization of the nervous system is generally found to be well-conserved, including the subepidermal plexus and the neurotransmitter expression. However, two exceptions are observed: (1) in parasitic worms that show the most variable organization of the nervous system of all groups (see shaded characters of the Neodermatida and the Rhabdocoela; Figure 7), most likely due to functional adaptations to a parasitic life style; and (2) in the Polycladida with inframuscular plexi that could either be a functional adaptation to quick escape response mechanisms and strong wave action in their habitat (rocky intertidal environments), or simply an ancestral state supporting a more basal position of the Polycladida among the Platyhelminthes.

(e) A transition from neuropile brains in the ancestor to encapsulated brains: There are two possible scenarios for the evolution of encapsulated brains (Figure 7): (1) the encapsulated brains in flatworms evolved at least four times independently in Polycladida, Proseriata, Rhabdocoela, and Prolecithophora, or (2) the encapsulated brain evolved once in the ancestor of the Rhabditophora, and was lost three times in Prorhynchida, Neodermata, and Tricladida. Although the rhabdocoels generally show a brain capsule, Strongylostoma simplex Meixner, 1915 is an exception.

(f) A convergent evolution of glial cells in different platyhelminth goups: Glial-like cells in flatworms have evolved convergently at least five times to provide support, isolation, or metabolic functions to the nerve cells of the CNS.

Although many efforts have been made to elucidate the phylogenetic relationships among the Platyhelminthes and to understand the major evolutionary transitions in the group, many open questions remain. Highly variable characters within each group, unresolved and often-conflicting 
molecular phylogenies, a deep evolutionary history of the phylum, and a serious lack of knowledge in many relevant groups are only some of the factors why this task has remained difficult. Consequently, this study provides not only original descriptive work on an understudied group of species, but also highlights some important gaps in our current understanding of the flatworn nervous system.

\section{Acknowledgments}

We thank Dr. Janet Voight from the Field Museum of Natural History, Chicago, Illinois, USA for specimens of Anocellidus profundus, and Dr. Bernhard Egger for the experimental advice on the ICCs. A UNESCO-L'OREAL International Fellowships Programme for Young Women in Life Sciences was awarded to D.M.B., and a Sigma Xi Grants-in-Aid for Research was granted to E.C.B. This work was supported in part by the Facultad de Ciencias at Universidad de los Andes and Fundación Banco de la República de Colombia to D.M.B, E.C.B. and F.D.B, and an "Apoio aos Novos Docentes" Grant from Universidade de São Paulo to F.D.B. This work also was supported by NSF grant DEB-0412932 to M.K.L.

\section{References}

Åkesson B (1958) A study of the nervous system of the Sipunculoideae, with some remarks on the development of the two species Phascolion strombi Montagu and Golfingia minuta Keferstein. Undersokningar over Oresund 38:1-249.

Bagunà $J$ and Riutort M (2004) Molecular phylogeny of the Platyhelminthes. Can J Zool 82:168-193.

Bailly X, Reichert H and Hartenstein V (2013) The urbilaterian brain revisited: Novel insights into old questions from new flatworm clades. Dev Genes Evol 223:149-157.

Biserova NM, Dudicheva VA, Terenina NB, Reuter M, Halton DW, Maule AG and Gustafsson MK (2000) The nervous system of Amphilina foliacea (Platyhelminthes, Amphilinidea), an immunocytochemical, ultrastructural and spectrofluorometrical study. Parasitology 121:441-453.

Bock S (1923) Boninia, a new polyclad genus from the Pacific. Nov Act Reg Soc Uppsala Ser 46:1-32.

Böckerman I, Reuter M and Timoshkin O (1994) Ultrastructural study of the central nervous system of endemic Geocentrophora (Prorhynchida, Platyhelminthes) from Lake Baikal. Acta Zool 75:47-55.

Bullock TH and Horridge GA (1965) Structure and Function in the Nervous Systems of Invertebrates. Vol. 2. W.H. Freeman and Co, San Francisco, 1719 pp.

Carranza S, Baguñà J and Riutort M (1997) Are the Platyhelminthes a monophyletic primitive group? An assessment using 18S rDNA sequences. Mol Biol Evol 14:485-497.

Cebrià F (2008) Organization of the nervous system in the model planarian Schmidtea mediterranea: An immunocytochemical study. Neurosci Res 61:375-384.

Chien P and Koopowitz H (1972) The ultrastructure of neuromuscular systems in Notoplana acticola, a free-living polyclad flatworm. Z Zellforsch Mikroskop Anat 133:277-288.
Chien PK and Koopowitz H (1977) Ultrastructure of nerve plexus in flatworms. III. The infra-epithelial nervous system. Cell Tissue Res 176:335-347.

Day TA, Maule AG, Shaw C and Pax RA (1997) Structureactivity relationships of FMRFamide-related peptides contracting Schistosoma mansoni muscle. Peptides 18:917-921.

Egger B, Gschwentner R and Rieger R (2007) Free-living flatworms under the knife: Past and present. Dev Genes Evol 217:89-104.

Egger B, Lapraz F, Tomiczek B, Müller S, Dessimoz C, Girstmair J, Skunca N, Rawlinson KA, Cameron CB, Beli E et al. (2015) A transcriptomic-phylogenomic analysis of the evolutionary relationships of flatworms. Curr Biol 25:1-7.

Ehlers U (1985) Das Phylogenetische System der Plathelminthes. Gustav Fischer Verlag, Stuttgart, 317 pp.

Fernandes MC, Alvares EP, Gama P and Silveira M (2003) Serotonin in the nervous system of the head region of the land planarian Bipalium kewense. Tissue Cell 35:479-486.

Forest DL and Lindsay SM (2008) Observations of serotonin and FMRFamide-like immunoreactivity in palp sensory structures and the anterior nervous system of spionid polychaetes. J Morphol 269:544-551.

Girstmair J, Schnegg R, Telford MJ and Egger B (2014) Cellular dynamics during regeneration of the flatworm Monocelis sp. (Proseriata, Platyhelminthes). Evo Devo 5:e37.

Golding DM (1992) Polychaeta: Nervous system. In: Harrison FW and Gardiner SL (eds) Microscopic Anatomy of Invertebrates. Vol. 7. Wiley-Liss, New York, pp 155-179.

Gustafsson MKS, Halton DW, Kreshchenko ND, Movsessian SO, Raikova OI, Reuter M and Terenina NB (2002) Neuropeptides in flatworms. Peptides 23:2053-2061.

Hadenfeldt D (1929) Das Nervensystem von Stylochoplana maculata und Notoplana atomata. Z wiss Zool 133:586638.

Halton DW and Gustafsson MKS (1996) Functional morphology of the platyhelminth nervous system. Parasitology 113:S47-S72.

Hanström B (1928) Vergleichende Anatomie des Nervensystems der wirbellosen Tiere, unter Berücksichtigung seiner Funktion. Springer Verlag, Berlin, 628 pp.

Hartenstein V and Ehlers U (2000) The embryonic development of the rhabdocoel flatworm Mesostoma lingua (Abildgaard, 1789). Dev Genes Evol 210:399-415.

Hyman LH (1941) Terrestrial flatworms from Canal Zone, Panama. Am Mus Novitat 1105:1-11.

Hyman LH (1951) The Invertebrates: Platyhelminthes and Rhynchocoela, the Acoelomate Bilateria. Vol. 2. McGraw-Hill, New York,. 550 pp.

Joffe BI and Reuter M (1993) The nervous system of Bothriomolus balticus (Proseriata): A contribution to the knowledge of the orthogon in the Plathelminthes. Zoomorphology 113:113-127.

Johnston RN, Shaw C, Halton DW, Verhaert P, Blair KL, Brennan GP, Price DA and Anderson PA (1996) Isolation, localization, and bioactivity of the FMRFamide-related neuropeptides GYIRFamide and YIRFamide from the marine turbellarian Bdelloura candida. J Neurochem 67:814-821.

Karling TG (1967) Zur Frage von dem systematischen Wert der Kategorien Archoophora und Neoophora (Turbellaria). Comm Biol Soc Fenn 30:1-11. 
Karling TG (1968) On the genus Gnosonesima Reisinger (Turbellaria). Sarsia 33:81-108.

Karling TG (1974) On the anatomy and affinities of the turbellarian orders. In: Riser NW and Morse MP (eds) Biology of the Turbellaria. McGraw-Hill, New York, pp 1-16.

Klagges BRE, Heimbeck G, Reifegerste R, Reisch D, Godenschwege TA, Buchner S, Hofbauer A and Buchner E (1996) Invertebrate synapsins: A single gene codes for several isoforms in Drosophila. J Neurosci 16:3154-3165.

Koopowitz H (1973) Primitive nervous systems. A sensory nerve net in the polyclad flatworm Notoplana acticola. Biol Bull 145:352.

Koopowitz H (1974) Some aspects of the physiology and organization of the nerve plexus in polyclad flatworms. In: Riser NW and Morse MP (eds) Biology of the Turbellaria. McGraw-Hill, New York, pp 198-212.

Koopowitz H and Chien P (1974) Ultrastructure of the nerve plexus in flatworms. I. Peripheral organization. Cell Tissue Res 155:337-351.

Koopowitz H and Chien P (1975) Ultrastructure of nerve plexus in flatworms. II. Sites of synaptic interactions. Cell Tissue Res 157:207-216.

Koopowitz H (1986) On the evolution of central nervous systems: Implications from polyclad turbellarian neurobiology. Hydrobiologia 132:79-87.

Kotikova EA (1986) Comparative characterization of the nervous system of the Turbellaria. Hydrobiologia 132:89-92.

Kotikova EA (1991) The orthogon of the Plathelminthes and main trends in evolution. Proc Zool Inst St Petersburg 241:88-111 [in Russian].

Kotikova EA and Raikova OI (2011) Architectonics of the central nervous system of Acoela, Platyhelminthes, and Rotifera. J Evol Biochem Physiol 44:95-108.

Krajniak KG and Greenberg MJ (1992) The localization of FMRFamide in the nervous and somatic tissues of Nereis virens and its effects upon the isolated esophagus. Comp Biochem Physiol C 101:93-100.

Kreshchenko N and Tolstenkov OO (2012) Some aspects of the immunolocalization of FMRFamide in the nervous system of turbellarians, Polycelis tenuis and Girardia tigrina. Acta Biol Hung 63(Suppl 2):83-87.

Ladurner P, Mair GR, Reiter D, Salvenmoser W and Rieger RM (1997) Serotonergic nervous system of two macrostomid species: Recent or ancient divergence? Invert Biol 116:178191.

Lang A (1884) Die Polycladen (Seeplanarien) des Golfes von Neapel und der angrenzenden Meeresabschnitte: Eine Monographie. Atlas. Vol. 11. W. Engelmann Verlag, Leipzig, 688 pp.

Laumer CE and Giribet G (2014) Inclusive taxon sampling suggests a single, stepwise origin of ectolecithality in Platyhelminthes. Biol J Linn Soc 111:570-588.

Laumer CE, Hejnol A and Giribet G (2015) Nuclear genomic signals of the "microturbellarian" roots of platyhelminth evolutionary innovation. Elife 4:e05503.

Litvaitis MK and Rhode K (1999) A molecular test of platyhelminth phylogeny: Inferences from partial 28rDNA sequences. Invert Biol 118:42-56.

Litvaitis MK, Bolanos DM and Quiroga SY (2010) When names are wrong and colours deceive: Unraveling the Pseudoceros bicolor species complex (Turbellaria, Polycldida). J Nat Hist 44:829-845.

Lowe CJ, Terasaki M, Wu M, Freeman RM, Runft L, Kwan K, Haigo S, Aronowicz J, Lander E, Gruber C et al. (2006) Dorsoventral patterning in hemichordates: Insights into early chordate evolution. PLoS Biol 4:e291.

Mäntylä K, Halton DW, Reuter M, Maule AG, Lindroos P, Shaw C and Gustafsson MKS (1998a) The nervous system of Tricladida. IV. Neuroanatomy of Planaria torva (Paludicola, Planaridae): An immunocytochemical study. Hydrobiologia 383:167-173.

Mäntylä K, Reuter M, Halton DW, Maule AG, Brennan GP, Shaw C and Gustafsson MKS (1998b) The nervous system of Procerodes littoralis (Maricola, Tricladida). An ultrastructural and immunoelectron microscopical study. Acta Zoologica 79:1-8.

Marks NJ, Johnston S, Maule AG, Halton DW, Shaw C, Geary TG, Moore S and Thompson DP (1996) Physiological effects of platyhelminths RFamide peptides on muscle-strip preparations of Fasciola hepatica (Trematoda, Digenea). Parasitology 113:393-401.

Maule AG, Halton DW, Shaw C and Thim L (1993) GNFFRFamide: A novel FMRFamide-immunoreactive peptide isolated from the sheep tapeworm, Moniezia expansa. Biochem Biophys Res Comm 193:1054-1060.

Minichev Y and Pugovkin AP (1979) Nervous system of the polyclad flatworm Notoplana atomata (O.F. Müller). Cah Biol Mar 20:181-188.

Monneypenny CG, Maule AG, Shaw C, Day TA, Pax RA and Halton DW (1997) Physiological effects of platyhelminth FMRFamide-related peptides (FaRPs) on the motility of the monogenean Diclidophora merlangi. Parasitology 115:281-288.

Moneypenny CG, Kreshchenko N, Moffett CL, Halton DW, Day TA and Maule AG (2001) Physiological effects of FMRFamide-related peptides and classical transmitters on dispersed muscle fibres of the turbellarian, Procerodes littoralis. Parasitology 122:447-455.

Moraczewski J, Czubaj A and Bakowska J (1977) Organization and ultrastructure of the nervous system in Catenulida (Turbellaria). Zoomorphologie 87:87-95.

Morris J, Cardona A, De Miguel-Bonet MDM and Hartenstein V (2007) Neurobiology of the basal platyhelminth Macrostomum lignano: Map and digital 3D model of the juvenile brain neuropile. Dev Genes Evol 217:569-584.

Morris J, Nallur R, Ladurner P, Egger B, Rieger R and Hartenstein $\mathrm{V}$ (2004) The embryonic development of the flatworm Macrostomum sp. Dev Genes Evol 214:220-239.

Mousley A, Moffett CL, Duve H, Thorpe A, Halton DW, Geary TG, Thompson DP, Maule AG and Marks NJ (2005) Expression and bioactivity of allatostatin-like neuropeptides in helminths. Int J Parasitol 35:1557-1567.

Newman LJ and Cannon LRG (1994) Pseudoceros and Pseudobioceros (Platyhelmithes, Polycladida, Pseudocerotidade) from eastern Australia and Papua New Guinea. Mem Qld Mus 37:205-266.

O'Gara BA, Abbasi A, Kaniecki K, Sarder F, Liu J and Narine LH (1999) Pharmacological characterization of the response of the leech pharynx to acetylcholine. J Exp Zool 284:729-741. 
Presnell JK and Schreibman M (1997) Humason's Animal Tissue Techniques. 5th edition The John Hopkins University Press, Baltimore, 572 pp.

Radojcic T and Pentreath VW (1979) Invertebrate glia. Prog Neurobiol 12:115-179.

Rawlinson KA and Litvaitis MK (2008) Cotylea (Polycladida): A cladistic analysis of morphology. Invertebr Biol 127:121138.

Reisinger E (1925) Untersuchungen am Nervensystem der Bothrioplana semperi Braun. Z Morphol Ökol Tiere 5:119149.

Reisinger E (1968) Xenoprorhynchus ein Modellfall für progressiven Funktionswechsel. Z zoolog Syst Evolutionsforsch 6:1-55.

Reisinger E (1970) Zur Problematik der Evolution der Coelomaten. J Zool Syst Evol Res 8:81-109.

Reisinger E (1972) Die Evolution des Orthogons der Spiralier und das Archicölomatenproblem. J Zool Syst Evol Res 10:1-43.

Reuter M (1988) Development and organization of nervous systems visualized by immunocytochemistry in three flatworm species. Fortschr Zool 36:181-184.

Reuter M and Gustafsson MK (1995) The flatworm nervous system: Pattern and phylogeny. In: Breidbach O and Kutsch W (eds) The Nervous System of Invertebrates: An Evolutionary and Comparative Approach. Birkhäuser, Basel, pp 2559.

Reuter, M, Gustafsson MKS, Mäntylä K and Grimmelikhuijzen CJP (1996) The nervous system of Tricladida. III. Neuroanatomy of Dendrocoelum lacteum and Polycelis tenuis (Plathelminthes, Paludicola): An immunocytochemical study. Zoomorphology 116:111-122.

Reuter M and Halton DW (2001) Comparative neurobiology of Platyhelminthes. In: Littlewood DTJ and Bray RA (eds) Interrelationships of the Platyhelmithes. Taylor and Francis, London and New York, pp 239-249.

Reuter M, Mäntylä K and Gustafsson MKS (1998) Organization of the orthogon - Main and minor nerve cords. Hydrobiologia 383:175-182.

Reuter M, Maule AG, Halton DW, Gustafsson MKS and Shaw C (1995) The organization of the nervous system in Plathelminthes. The neuropeptide F-immunoreactive pattern in Catenulida, Macrostomida, Proseriata. Zoomorphology 115:83-97.

Reuter M, Wikgren M and Lehtonen M (1986) Immunocytochemical demonstration of 5-HT-like and FMRF-amide-like substances in whole mounts of Microstomum lineare (Turbellaria). Cell Tissue Res 246:7-12.

Rieger RM, Tyler S, Smith JPS and Rieger GE (1991) Platyhelminthes: Turbellaria. In: Harrison FW and Bogitsh BJ (eds) Microscopic Anatomy of Invertebrates. Platyhelminthes and Nemertinea. Wiley-Liss, NewYork, pp 7-140.

Ruppert EE and Barnes RD (1994) Invertebrate Zoology. Saunders College Publishing, New York, 1056 pp.

Schürmann FW (1995) Common and special features of the nervous system of Onychophora: A comparison with Arthropoda, Annelida and some other invertebrates. In: Breidbach O and Kutsch W (eds) The Nervous Systems of Invertebrates: An Evolutionary and Comparative Approach. Birkhäuser, Basel, pp 139-158.

Shishov BA (1991) Aminergic elements in the nervous system of helminthes. In: Sakharov DA and Winlow W (eds) Simpler Nervous Systems. Vol 13. Manchester University Press, Manchester, pp 113-137.

Sluys R (1989) A monograph of the marine triclads. A.A. Balkema, Rotterdam and Brookfield, $463 \mathrm{pp}$.

Steinböck O (1927) Monographie der Prorhynchidae (Turbellaria) Z Morphol Ökol Tiere 8:538-662.

Steinböck O and Reisinger E (1924) On Prorhynchus putealis Haswell, with a description of a new species of the genus. Quart J Micr Sci 68:443-451.

Strausfeld NJ, Strausfeld CM, Loesel R, Rowell D and Stowe S (2006) Arthropod phylogeny: Onychophoran brain organization suggests an archaic relationship with a chelicerate stem lineage. Proc Biol Sci 273:1857-1866.

Sukhdeo SC and Sukhdeo MV (1988) Immunohistochemical and electrochemical detection of serotonin in the nervous system of Fasciola hepatica, a parasitic flatworm. Brain Res 463:57-62.

Timoshkin OA (1991) Turbellaria Lecithoepitheliata: Morphology, systematics, phylogeny. Hydrobiologia 227:323-332.

Tomer R, Denes AS, Tessmar-Raible K and Arendt D (2010) Profiling by image registration reveals common origin of annelid mushroom bodies and vertebrate pallium. Cell 142:800-809.

Villar D and Schaeffer DJ (1993) Morphogenetic action of neurotransmitters on regenerating planarians - A review. Biomed Env Sci 6:327-347.

Von Graff L (1899) Monographie der Turbellarien II. Tricladida Terricola (Landplanarien). Wilhelm Engelmann Verlag, Leipzig 574 pp.

Webb RA and Mizukawa K (1985) Serotonin-like immunoreactivity in the cestode Hymenolepis diminuta. J Comp Neurol 234:431-440.

Wikgren MC and Reuter M (1985) Neuropeptides in a microturbellarian - Whole mount immunocytochemistry. Peptides $6: 471-475$.

Associate Editor: Igor Schneider

License information: This is an open-access article distributed under the terms of the Creative Commons Attribution License, which permits unrestricted use, distribution, and reproduction in any medium, provided the original work is properly cited. 